No 4078

Studia nad Autorytaryzmem i Totalitaryzmem 43, nr 4

Wrocław 2021

https://doi.org/10.19195/2300-7249.43.4.31

\author{
LIDIA SIWIK \\ ORCID: 0000-0002-2223-3492 \\ Uniwersytet Wrocławski \\ lidia.siwik@uwr.edu.pl
}

\title{
Wpływ władzy totalitarnej na sposoby regulacji polskiego prawa gospodarczego
}

\begin{abstract}
Slowa kluczowe: autorytaryzm, totalitaryzm, zasada jedności prawa cywilnego, prawo gospodarcze w PRL, prawo handlowe podczas rządów autorytarnych, prawo handlowe w państwie totalitarnym, sposoby regulacji ustroju gospodarczego, totalitaryzm a prawo gospodarcze, autorytaryzm a prawo gospodarcze, swoboda przedsiębiorczości, swoboda działalności gospodarczej.
\end{abstract}

\section{THE INFLUENCE OF TOTALITARIAN POWER ON THE WAYS OF REGULATING POLISH ECONOMIC LAW}

\begin{abstract}
In the current legal order there are two ways of regulating economic law. According to the dualist concept, economic relations are treated as separate from civil law relations, while, according to the principle of the unity of civil law, the aspects of economic turnover are a specialized part of civil law. In Poland, the dualist concept was replaced under communist authoritarian rule by the principle of the unity of civil law in order to emphasize the low usefulness and lack of practical relevance of economic turnover, which was replaced almost entirely by socialized turnover conducted by economic units with state status. Despite the departure from totalitarian rule and in the current system of social market economy, the principle of the unity of civil law has persisted. The paper shows that the principle of the unity of civil law, although instrumentally treated by authoritarian governments, has a number of advantages that allow it to function successfully in the conditions of freedom of entrepreneurship in the European Union and in the face of political changes that took place in Poland at the turn of the twenty-first century.

Keywords: authoritarianism, totalitarianism, principle of the unity of civil law, commercial law in the Polish People's Republic, commercial law during authoritarian rule, commercial law in a totalitarian state, ways of regulating the economic system, totalitarianism and economic law, authoritarianism and economic law, freedom of enterprise, freedom of economic activity.
\end{abstract}


Określenie zakresu prawa cywilnego budziło w literaturze wiele kontrowersji, zwłaszcza jeżeli dotyczyło prywatnoprawnej regulacji obrotu handlowego (gospodarczego), w związku z różnymi ustrojami gospodarczymi, w szczególności tymi o podłożu autorytarnym i totalitarnym. Na tym gruncie historycznie zrodziły się dwie teorie ${ }^{1}$. Koncepcja dualistycznej regulacji stosunków majątkowych przewidywała odrębne unormowania dla obrotu powszechnego i gospodarczego, chociaż w stosunkach gospodarczych posługiwano się cywilistyczną metodą regulacji w postaci umowy. Z kolei przeciwstawna zasada jedności prawa cywilnego zakładała, iż stosunki gospodarcze zostaną objęte prawem cywilnym, natomiast prawo handlowe stanowić będzie jedynie wyspecjalizowany jego dział. O przyjęciu którejś z koncepcji musi zdecydować ustawodawca, przesądzając jednocześnie, czy trzon przepisów prawa handlowego (gospodarczego) znajdować się będzie w kodeksie cywilnym czy też stworzony zostanie odrębny kodeks handlowy. W zależności od przyjętej koncepcji prawo handlowe w systemach prawnych zajmowało różne miejsce i odmienny był zakres prawa cywilnego. Również polskie prawo prywatne przeszło znamienną ewolucję. Obowiązujące w Polsce ustroje totalitarne, które zakładały uspołecznienie środków produkcji, wymiany, komunikacji i kredytu oraz opierały się na narodowym planie gospodarczym $^{2}$, zmarginalizowały znaczenie prawa handlowego skutkujące odejściem od zasady dualizmu regulacji stosunków majątkowych w kierunku zasady jedności prawa cywilnego. Niniejsze opracowanie stanowi próbę zastanowienia się, czy ustrój gospodarczy w Polsce będzie kluczowym czynnikiem determinującym przyjęcie jednej z tych zasad i czy w związku z odejściem od ustrojów autorytarnych $^{3}$ utrzymanie zasady jedności prawa cywilnego ma swoje uzasadnienie.

\section{Tendencje w początkach kształtowania się prawa handlowego}

Początkowo prawem stosunków gospodarczych było prawo cywilne. Jego geneza i rozwój wiązały się właśnie $\mathrm{z}$ rozwojem gospodarki. $\mathrm{W}$ miarę jednak wzrostu znaczenia stosunków handlowych zaczęły pojawiać się odrębne zwyczajowe normy, które były zaczątkiem tego, co obecnie nazywamy właśnie prawem handlowym. W średniowieczu prawo stanu kupieckiego wykształciło własne zasady obowiązujące w obrocie, gdyż ówczesne prawo cywilne nie było dostosowane do obrotu kupieckiego, który wymagał elastycznych norm prawnych,

1 A. Stelmachowski, Wstęp do teorii prawa cywilnego, Warszawa 1984, s. 58; A. Wolter, J. Ignatowicz, K. Stefaniuk, Prawo cywilne. Zarys części ogólnej, Warszawa 1999, s. 23.

2 Por. art. 7 ust. 1 Konstytucji PRL z 22 lipca 1952 roku (Dz.U. z 1976 r. Nr 7, poz. 36).

3 Por. M. Makowska, M. Makowski, Zakaz propagowania komunizmu lub innego ustroju totalitarnego przez nazwy jednostek organizacyjnych, jednostek pomocniczych gminy, budowli, obiektów i urządzeń użyteczności publicznej oraz pomniki. Komentarz, Warszawa 2019, kom. do art. 1. 
niekrępujących nadmiarem formalizmu ${ }^{4}$. Natomiast najpełniej prawo handlowe rozwinęło się w warunkach kapitalizmu liberalnego, gdzie traktowane było jako część prawa prywatnego. Mówiono wówczas o dualizmie prawa prywatnego obejmującym dwie niezależne gałęzie prawa (cywilne i handlowe).

W XIX wieku prawo handlowe doczekało się swojej regulacji w niektórych państwach, z kolei w innych tylko szczątkowo wyodrębniono swoiste dla niego normy i instytucje. $Z$ czasem zakresem swym objęło nie tylko działalność handlową, ale wszelką aktywność podmiotów prowadzących działalność gospodarczą. Pierwsze poważne unormowania prawa handlowego to niewątpliwie francuski kodeks handlowy z 1807 roku, przyjmujący za centralną kategorię pojęcie czynności handlowych, oraz niemiecki kodeks handlowy z 1892 roku, gdzie naczelne znaczenie miało pojęcie kupca. Z kolei podstawowym źródłem dla stosunków handlowych w Szwajcarii było prawo zobowiązań z 1911 roku, stanowiące formalnie księgę II szwajcarskiego kodeksu cywilnego. Nigdy bowiem nie wprowadzono tam podziału na prawo cywilne i handlowe, co wynikało z lasowanej zasady komercjalizacji prawa cywilnego. Zgodnie z tą zasadą prawo cywilne recypowało normy prawa handlowego, które stały się obowiązującymi także w zwykłym obrocie cywilnym ${ }^{5}$. Podobnie w prawie włoskim obrót handlowy uregulowany został w kodeksie cywilnym.

W europejskich systemach prawnych wykształciły się więc dwa sposoby regulacji prywatnoprawnych dotyczących podmiotów prowadzących działalność gospodarczą ${ }^{6}$. Ustawodawstwo francuskie, niemieckie i belgijskie wyodrębniło regulację stosunków profesjonalnych w postaci odrębnego kodeksu, zaś w prawie szwajcarskim, włoskim, holenderskim oraz w krajach anglosaskich stosunki handlowe ujmowane są razem z cywilnymi.

\section{Dualizm regulacji stosunków prywatnoprawnych w RP}

Po zakończeniu pierwszej wojny światowej na obszarze RP panował chaos w zakresie regulacji prawnych. Najczęstszymi stosunkami prawnymi łączącymi Polaków z różnych dzielnic były obligacyjne, a cały obrót handlowy odbywał się właśnie za pośrednictwem umów obligacyjnych ${ }^{7}$. Konieczności ujednolicenia prawa $\mathrm{w}$ dziedzinie zobowiązań, przez wzgląd na sferę gospodarczą, skłoniły do kodyfikacji prawa zobowiązań i handlowego, a także uchwalenia dwóch

${ }^{4}$ Pierwszym aktem ustawodawczym w tej dziedzinie był francuski Ordonance du comerce z 1673 roku zwany Code Savary.

${ }^{5}$ Por. A. Wolter, J. Ignatowicz, K. Stefaniuk, op. cit., s. 23.

${ }^{6}$ A. Całus, Prawo cywilne i handlowe państw obcych, Warszawa 1979, s. 13-15; S. Janczewski, Prawo handlowe. Wekslowe i czekowe, Warszawa 1946, s. 9-18; Prawo handlowe, red. J. Okolski, Warszawa 1999, s. II n.

7 R. Longchamps de Bérier, Polskie prawo cywilne. Zobowiązania, Lwów 1939, s. 3. 
niezależnych kodeksów. Postulowano wówczas, aby regulacje odnoszące się do obrotu handlowego realizowały konieczność zapewnienia bezpieczeństwa, pewności i szybkości obrotu ${ }^{8}$.

Polski kodeks handlowy z 27 czerwca 1934 roku$^{9}$ wzorował się na swoim niemieckim odpowiedniku. Stanowił ogólne unormowanie dotyczące materii związanych z obrotem handlowym. Właśnie oddzielenie obrotu powszechnego od gospodarczego przesądziło o przyjęciu teorii dualizmu regulacji prawnej stosunków majątkowych w oparciu o pojęcie kupca i czynności handlowych. Przez niemal 30 lat kodeks i pozakodeksowe ustawy handlowe stanowiły główne źródła prawa handlowego. Prawo cywilne miało zastosowanie do stosunków handlowych subsydiarnie, a mianowicie, gdy ani kodeks handlowy, ani ustawy szczególne, ani też prawo zwyczajowe danego stosunku nie regulowało (art. $1 \mathrm{kh})^{10}$.

W Polsce przedwojennej ogół stosunków w zakresie obrotu prawnogospodarczego normowało zatem prawo handlowe. Stanowiło ono zbiór przepisów prywatnoprawnych powstających na podłożu obrotu gospodarczego, o ile z mocy specjalnego przepisu ustawy stosunki te nie były wyłączone spod działania tego prawa ${ }^{11}$. Stąd od uchwalenia kodeksu handlowego aż do wejścia w życie kodeksu cywilnego z 1964 roku w polskim systemie obowiązywała koncepcja dualistycznej regulacji stosunków majątkowych przez prawo cywilne i handlowe, a jednocześnie prawo handlowe stanowiło odrębną dyscyplinę prawniczą.

\section{Początki zasady jedności prawa cywilnego}

Zmiana ustroju społeczno-politycznego i odejście od gospodarki rynkowej po drugiej wojnie światowej wywarły decydujący wpływ na faktyczne znaczenie i zastosowanie prawa handlowego. Nacjonalizacja zakładów przemysłowych i handlowych wyjęła spod działania kodeksu najpoważniejsze przedsiębiorstwa. Nowa sytuacja gospodarcza i polityczna stwarzała konieczność dostosowania prawa do zaistniałych realiów, również w zakresie obrotu gospodarczego. W okresie tym niezwykle kontrowersyjny okazał się problem wyodrębnienia kompleksowej gałęzi prawa gospodarczego.

Generalnie istniały dwie grupy poglądów:

1. Wewnętrzne wyodrębnienie prawa gospodarczego w zakresie podstawowych gałęzi prawa, w których występuje problematyka gospodarczo-prawna, między innymi prawa cywilnego i administracyjnego.

${ }^{8}$ Szerzej zob. J. Namitkiewicz, Próba charakterystyki i określenia prawa handlowego, „Przegląd Prawa Handlowego" 1925, nr 2.

9 Rozporządzenie prezydenta RP z dnia 27 czerwca 1934 roku - Kodeks handlowy (Dz.U. z 1934 r. Nr 57, poz. 502 ze zm.), dalej: kh.

10 Szerzej zob. M. Allerhand, Komentarz do kodeksu handlowego, Lwów 1935.

11 S. Janczewski, op. cit., s. 8. 
2. Zewnętrzne wyodrębnienie prawa gospodarczego w odniesieniu do podstawowych gałęzi prawa. W ramach tej teorii wyróżniono dwie koncepcje:

a. traktującą prawo gospodarcze jako podstawową gałąź prawa wyodrębnioną od innych ze względu na problematykę gospodarczą; wym $^{12}$.

b. stanowiącą ponadgałęziową syntezę, gałąź o charakterze komplekso-

Pojęcie prawa gospodarczego jako przedmiotu odrębnej dyscypliny prawniczej pojawiło się w niemieckiej nauce prawa. Do zakresu tej dyscypliny dzielonej nieraz ze względu na jej kompleksowość na kilka działów włączono prawo handlowe, przemysłowe, przewozowe, ubezpieczeń, patentowe itp. Łączono zatem cały szereg różnych dyscyplin prawniczych, niemal wyłącznie kompleksowych $\mathrm{w}$ jedną wielką dyscyplinę prawniczą. Koncepcję prawa gospodarczego podjęto w Związku Radzieckim jako myśl o szczególnym prawie socjalistycznej gospodarki planowej, różniącym się od prawa cywilnego i zaprzeczającym jego zasadzie jedności oraz stanowiącym odrębną gałąź prawa. Głównymi jednak przesłankami wysuwanymi w rozwoju tej koncepcji były względy polityczne. Koncepcje kompleksowego prawa gospodarczego postulowały odrębne i łączne traktowanie norm oraz stosunków prawnych związanych z działalnością gospodarczą. Takie ujęcie przyjęto w nauce socjalistycznej prawa gospodarczego, szczególnie w Czechosłowacji i NRD. Do prawa gospodarczego włączone były wówczas normy dotyczące zarówno kierowania gospodarką, jak i urzeczywistnienia działalności gospodarczej.

Po burzliwych dyskusjach w PRL zdecydowano się na kompromisowe rozwiązanie oparte na założeniu jedności prawa cywilnego ${ }^{13}$. Zasadę tę proklamowano w art. $1 \mathrm{kc} \mathrm{z} 1964$ roku. Zgodnie z dyspozycją art. VI przepisów wprowadzających kodeks cywilny, kodeks handlowy oraz przepisy wprowadzające kodeks handlowy zostały uchylone, z wyjątkiem unormowań dotyczących spółek jawnych, spółki z ograniczoną odpowiedzialnością i spółki akcyjnej. W stosunku do nich dalej pozostały w mocy również przepisy kodeksu handlowego oraz

12 Szerzej zob. S. Grzybowski, System prawa cywilnego. Część ogólna, Wrocław 1985, s. 25-28; J. Wasilkowski, Kodeks cywilny PRL a zagadnienie prawa gospodarczego. Tezy referatu przedstawionego na zebraniu Komitetu Nauk Prawnych PAN 12 II 1960 r., „Państwo i Prawo” 1960, nr 3, s. 413-433; S. Włodyka, Problem „prawa gospodarczego”, „Studia Cywilistyczne” 5, 1964, s. 67-165; idem, Polskie koncepcje prawa gospodarczego, „Przegląd Ustawodawstwa Gospodarczego" 1980, nr 4, s. 101-105; idem, Prawo gospodarcze. Zarys systemu. Część ogólna. t. 1, Warszawa 1981, s. 11-13; A. Wolter, Czy renesans koncepcji prawa gospodarczego?, „Przegląd Ustawodawstwa Gospodarczego" 1957, nr 3; E. Iserzon, Wokót koncepcji prawa gospodarczego, „Przegląd Ustawodawstwa Gospodarczego" 1956, nr 10, s. 363-370; również bogata cytowana w tych opracowaniach literatura.

13 Szerzej zob. W. Czachórski, Prace nad kodyfikacją prawa cywilnego, „Studia Prawnicze” 1970, nr 26-27, s. 17. 
przepisy wprowadzające ten kodeks o firmie, prokurze i rejestrze handlowym ${ }^{14}$. Czynności handlowe, w szczególności umowa sprzedaży, umowa rachunku bankowego, umowa agencyjna, komisu, spedycji, przewozu i składu uregulowane zostały bezpośrednio przez kodeks cywilny. Po tych zmianach regulacja kodeksu handlowego była w dużej mierze bezużyteczna, a przepisy odnoszące się do obrotu gospodarczego (zwanego wówczas uspołecznionym) stały się częścią prawa cywilnego, o ile miały charakter cywilistyczny. Zasada jedności prawa cywilnego odnosiła się głównie do obrotu uspołecznionego, gdyż zdecydowana większość jednostek gospodarujących miała charakter państwowy z uwagi na upaństwowienie w PRL niemalże całej gospodarki, a dawne jednostki gospodarki uspołecznionej dały podwaliny do dzisiejszych spółek komunalnych ${ }^{15}$. Zdaniem Andrzeja Stelmachowskiego zasada jedności prawa cywilnego praktycznie nie miała wówczas istotnego znaczenia, a jej głównym celem było odrzucenie koncepcji wyodrębnienia tak zwanego prawa gospodarczego, które zagrażało tradycyjnemu prawu cywilnemu ${ }^{16}$. Zwycięstwo tej teorii uniemożliwiło więc powstanie odrębnej dziedziny prawa - prawa gospodarczego — stanowiącego kompleks norm o różnym charakterze.

Derogacja większości przepisów kodeksu handlowego świadczyła dobitnie o odejściu od zasady dualizmu regulacji w prawie prywatnym. Miała ona ten skutek - jak powszechnie przyjmuje się w literaturze ${ }^{17}$ — że przepisy te nie stanowią odrębnej gałęzi prawa ani nawet dyscypliny prawniczej. Są natomiast częścią prawa cywilnego, a ściślej mówiąc, wchodzą w zakres wyspecjalizowanej dziedziny prawa cywilnego, to znaczy - prawa obrotu gospodarczego. Główne kryterium wyodrębnienia regulacji prawnej w kodeksie cywilnym stanowiła własność społeczna środków produkcji, stąd wiele przepisów odnosiło się do obrotu między jednostkami gospodarki uspołecznionej (dalej j.g.u.). Znacząca część stosunków cywilnoprawnych mających charakter gospodarczy objęta została przez kodeks cywilny właśnie pojęciem stosunków między j.g.u., między j.g.u. a osobami fizycznymi oraz osobami prawnymi niebędącymi jednostkami gospodarczymi. Wobec takiego kontekstu społeczno-gospodarczego nieprzydatne było posługiwanie się pojęciem kupca. $\mathrm{Z}$ tego powodu klauzulą derogacyjną uchylono przepisy kodeksu handlowego wyjaśniające pojęcie kupca oraz kupca rejestrowego, a także większość przepisów księgi II kodeksu zatytułowanej Czynności handlowe.

Zasada jedności prawa cywilnego nie została wprowadzona konsekwentnie, chociaż w samym kodeksie znalazły się przepisy dotyczące podmiotów, które

14 Dla stosunków gospodarczych utrzymane zostały ponadto w mocy przepisy art. 518-524 i $531 \mathrm{kh}$.

15 Por. R. Szczepaniak, Węłowe problemy stosowania prawa prywatnego w sektorze publicznym, „Ruch Prawniczy, Ekonomiczny i Socjologiczny” 78, 2016, z. 4, s. 108-109.

16 A. Stelmachowski, op. cit., s. 59.

17 A. Wolter, J. Ignatowicz, K. Stefaniuk, op. cit., s. 23; S. Grzybowski, op. cit., s. 42. 
w sposób trwały i zawodowo prowadziły działalność gospodarczą, oraz objęto działalność handlową regulacją prywatnoprawną, co dało możliwość zachowania niektórych zasad gospodarki, takich jak na przykład swobody umów. Niemniej jednak wiele przepisów, przede wszystkim art. 2 i $384 \mathrm{kc}$ w ówczesnym brzemieniu $^{18} \mathrm{i}$ art. IX przepisów wprowadzających kc, stanowiło zaprzeczenie tej zasady i stworzyło podwaliny do wykształcenia tak zwanego prawa obrotu uspołecznionego ${ }^{19}$, które w pewnym sensie w realiach gospodarki planowej zajęło miejsce prawa handlowego ${ }^{20}$. Regulacji dotyczących obrotu uspołecznionego nie można było uznać za odrębną dziedzinę prawa, pomimo wielu swoistych, charakterystycznych cech. Specyfika bowiem regulacji obrotu gospodarczego między tak zwanymi jednostkami gospodarki uspołecznionej w pewnym sensie odbiegała od zasad prawa cywilnego. Niemniej jednak kryteria wyodrębnienia tej dziedziny, oparte na wyróżnieniu własności społecznej, wówczas dominującej w życiu gospodarczym, nigdy nie były dostatecznie jasne i wystarczające dla wytyczenia jednoznacznej granicy.

Reasumując, w ówczesnych warunkach zrezygnowanie $\mathrm{z}$ dualizmu w regulacji stosunków gospodarczych należy oceniać pozytywnie. Zdaniem J. Frąckowiaka „uniknięto w ten sposób, przynajmniej od strony teoretycznej, stwarzania jeszcze szerszych możliwości dla budowania regulacji prawnej dotyczącej stosunków gospodarczych, która byłaby pozbawiona w szerszym zakresie elementów cywilnoprawnych"21.

\section{Zasada jedności prawa cywilnego w okresie transformacji społeczno-gospodarczej}

Reforma ustroju w 1989 roku i powrót do gospodarki rynkowej zapoczątkowały w Polsce w praktyce życia gospodarczego wielki renesans właśnie prawa handlowego i wielu jego tradycyjnych instytucji, głównie spółek, weksli, czeków, upadłości. Na nowo odżyły i nabrały nowego znaczenia pojęcia dobrych obyczajów oraz uczciwości kupieckiej.

Reforma gospodarcza i zmiany ustrojowe stały się dla ustawodawcy nowym wyzwaniem. Niewątpliwie wywołały one intensywną działalność legislacyjną w zakresie prawa gospodarczego, mającą na celu dostosowanie do jej zasad i zamierzeń

18 Zagadnienie prawne związane z obrotem gospodarczym między j.g.u. mogły być regulowane przez akty rzędu niższego niż ustawa.

19 Szerzej zob. S. Buczkowski, Z.K. Nowakowski, Prawo obrotu uspołecznionego, Warszawa 1974, passim.

20 Szerzej zob. K. Kruczalak, Problem stosowania niektórych przepisów kodeksu handlowego, „Prawo i Państwo” 1987, nr 6, s. 60-61.

21 Tak J. Frąckowiak, Ustawodawstwo dotyczace przedsiębiorców pod rządami zasady jedności prawa cywilnego, „Przegląd Prawa Handlowego” 2000, nr 11, s. 2. 
przepisów prawa gospodarczego, a także adaptację unormowań do aktualnych potrzeb $^{22}$. W ustawie z 1988 roku o działalności gospodarczej ${ }^{23}$ po raz pierwszy znalazła swój normatywny wyraz zasada wolności gospodarczej. Ustawodawca nie zdecydował się na restytucję zasady dualizmu poprzez przywrócenie kodeksu handlowego, lecz utrzymał istniejącą jedność prawa cywilnego ${ }^{24}$, co oznaczało objęcie całokształtu stosunków majątkowych między wszystkimi podmiotami regulacją kodeksową. Co prawda, w ramach prawa cywilnego doszło do wyodrębnienia prawa obrotu gospodarczego ${ }^{25}$, niemniej jednak w kodeksie cywilnym nie uregulowano najważniejszej kwestii ustalenia kryteriów decydujących o rozgraniczeniu ich od przepisów odnoszących się do obrotu powszechnego ${ }^{26}$. Tym samym trudno było wytyczyć linię demarkacyjną pomiędzy obrotem profesjonalnym a nieprofesjonalnym. Nowelizacja kodeksu cywilnego przyniosła bowiem uchylenie pojęcia jednostki gospodarki uspołecznionej, natomiast nie wprowadzono nowego, zastępującego dotychczasowe, określenia podmiotu prowadzącego działalność gospodarczą ${ }^{27}$. Pomimo więc utrzymania zasady jedności prawa cywilnego podstawowe określenie dla wyróżnienia obrotu powszechnego od gospodarczego znalazło się poza kodeksem cywilnym, co spowodowało utratę przez niego pozycji podstawowego aktu prawnego dla stosunków gospodarczych. Można wręcz stwierdzić, iż przyjęta zasada praktycznie nie znajdowała potwierdzenia w treści kodeksu.

$\mathrm{W}$ istocie nastąpiło rozproszenie kluczowych unormowań dotyczących stosunków z udziałem podmiotów gospodarczych w trzech ustawach: kodeksie cywilnym, utrzymanych w mocy przepisach kodeksu handlowego oraz ustawie o działalności gospodarczej. Istniejący wówczas stan prawny był przedmiotem krytyki w literaturze, gdyż wprowadził liczne niejasności dotyczące zakresu pojęcia podmiotu gospodarczego, regulacje firmy, prokury oraz rejestru, bez uzasadnionej przyczyny, pozostawały wyłącznie na użytek spółek handlowych, a poza tym w praktyce dla uniknięcia problemów z rejestracją i opodatkowaniem spółek z kodeksu handlowego powstawały, na niespotykaną dotychczas skalę, spółki

22 Szerzej zob. I. Weiss, Przeobrażenia prawa gospodarczego $w$ warunkach reformy gospodarczej, [w:] Problemy kodyfikacji prawa cywilnego. Księga pamiątkowa ku czci prof. Z. Radwańskiego, red. S. Sołtysiński, Poznań 1990, s. 105-121.

${ }^{23}$ Ustawa z dnia 23 grudnia 1988 roku o działalności gospodarczej (Dz.U. z 1988 r. Nr 41, poz. 324 ze zm.).

24 Por. uchwałę składu siedmiu sędziów z dnia 7 kwietnia 1993 roku (III CZP 23/93, OSNCP 1993/10, poz. 172, s. 1).

${ }^{25}$ K. Kruczalak, Prawo obrotu gospodarczego, cz. 1. Zagadnienia ogólne, cz. 2. Prawo przedsiębiorstw, Gdańsk 1989, passim.

26 Szerzej zob. A. Całus, Problematyka handlowa w reformie kodeksu cywilnego, „Przegląd Ustawodawstwa Gospodarczego" 1990, nr 8-10.

27 Wraz z nowelą pojawiło się tylko pojęcie przedsiębiorstwa w znaczeniu przedmiotowym - art. $55^{1}, 55^{2}, 55^{3} \mathrm{kc}$. 
cywilne ${ }^{28}$. Niewątpliwie następujące wówczas zmiany przyczyniły się do unowocześnienia polskiego prawa handlowego, ale nadal brak było przejrzystych i uporządkowanych unormowań w najistotniejszych kwestiach. Po uchyleniu przepisów dotyczących kupca, a także wyeliminowaniu jednostek gospodarki uspołecznionej definicja o podstawowym znaczeniu dla określenia osób prowadzących działalność gospodarczą znajdowała się poza kodeksem cywilnym.

\section{Ukoronowanie zasady jedności prawa cywilnego}

Postępujące modyfikacje przepisów zmierzały konsekwentnie do stworzenia lepszych podstaw i gwarancji odpowiadających założeniom jedności prawa cywilnego. Wyrazem tych dążeń prawodawcy było uchwalenie w 2000 roku kodeksu spółek handlowych ${ }^{29}$, którego przedmiot regulacji stanowiła problematyka wyłącznie spółek handlowych jako podmiotów powołanych do prowadzenia działalności gospodarczej. Wąski zakres tej ustawy nie uzasadniał wniosku o wyodrębnieniu prawa handlowego jako odrębnej dyscypliny prawniczej, a stanowił wręcz ostatecznie o przyjęciu przez ustawodawcę koncepcji jedności prawa cywilnego ${ }^{30}$.

Ukoronowaniem tej zasady była natomiast ostatnia nowelizacja kodeksu cywilnego z $2003 \mathrm{roku}^{31}$. Za postulatami nauki $\mathrm{w}$ nim pojawiły się uregulowania najistotniejszych zagadnień w prawie handlowym, takich jak przedsiębiorca, firma, prokura. Ponadto modyfikowano i dodano nowe przepisy dotyczące obrotu z udziałem podmiotów zajmujących się profesjonalnie działalnością gospodarczą i zawodową. Zawarcie legalnej definicji przedsiębiorcy w kodeksie cywilnym pozwoliło na stworzenie uniwersalnego kryterium wyodrębnienia obrotu powszechnego od profesjonalnego, przy jednoczesnym utrzymaniu jedności prawa cywilnego, którego prawo handlowe stanowi wyspecjalizowaną część. Wprowadzone przepisy uzupełniły tym samym istniejącą $\mathrm{w}$ systemie lukę prawną.

\section{Zalety zasady jedności prawa cywilnego w świetle wolności gospodarczej}

Polskie prawo gospodarcze przeszło, jak wynika z niniejszego opracowania, swoistą ewolucję. Opierając się na niemieckich wzorcach w początkowej fazie

28 Szerzej zob. J. Frąckowiak, op. cit., s. 4-5.

29 Ustawa z dnia 15 września 2000 roku - Kodeks spółek handlowych (Dz.U. z 2000 r. $\mathrm{Nr}$ 94, poz. 1037 ze zm.).

30 A. Szajkowski, [w:] S. Sołtysiński et al., Kodeks spółek handlowych. Komentarz do art. 1-150, t. 1, Warszawa 2012, s. 4-5.

31 Ustawa z dnia 14 lutego 2003 roku o zmianie ustawy - Kodeks cywilny oraz niektórych innych ustaw (Dz.U. z 2003 r. Nr 49, poz. 408). 
kształtowania się obrotu handlowego, przyjęło koncepcje odrębnych regulacji prawa cywilnego i handlowego. W okresie gospodarki centralnie sterowanej nie zdecydowano się na połączenie regulacji prywatno- i publicznoprawnej ani stworzenie kompleksowego prawa gospodarczego. Stosunki majątkowe z udziałem j.g.u. miały podlegać, zgodnie z zasadą jedności prawa cywilnego, prawu cywilnemu. Pomimo powrotu pod koniec XX wieku do gospodarki rynkowej, zachowano przyjętą wcześniej koncepcje regulacji prywatnoprawnej i w systemie prawnym nie powstała odrębna gałąź prawa handlowego.

Do tej pory zarówno we Francji, Niemczech, jak i Belgii, a także w kilku innych państwach Unii Europejskiej zagadnienia transakcji i wszelkich czynności handlowych dokonywanych przez podmioty gospodarcze regulowane są przez odrębne kodeksy handlowe i związane z nimi ustawy. Jednak pomimo wzorowania się w Polsce międzywojennej w początkowych latach tworzenia dyscypliny prawa handlowego na systemie niemieckim, zmiany w polskim prawie prywatnym zmierzały raczej w kierunku rozwiązań przyjętych w Szwajcarii, Włoszech czy Anglii, gdzie nie ma odrębnego prawa handlowego, niż systemów prawnych, w których istnieją samodzielne kodeksy handlowe. Jest to zgodne z ogólną tendencją, którą w ostatnich latach daje się zauważyć w większości państw Unii Europejskiej. Trudności w znalezieniu precyzyjnych kryteriów oddzielenia prawa cywilnego od handlowego skłaniają coraz więcej ustawodawców do odchodzenia od zasady dualizmu w regulacji stosunków gospodarczych. Również w przygotowywanym europejskim kodeksie cywilnym przyjmuje się zasadę jedności prawa cywilnego ujmującego stosunki handlowe jako jego integralną część 32 .

Utrzymanie zasady jedności prawa cywilnego ma o tyle istotne znaczenie, że dzięki niej profesjonaliści mogą korzystać z całego arsenału narzędzi prawnych i środków ochronnych znanych prawu cywilnemu. $Z$ kolei stworzenie kompleksowego syntetycznego kodeksu gospodarczego, w skład którego wchodziłyby przepisy różnych działów prawa, działające w odmienny sposób, uniemożliwiałoby uwzględnienie specyfiki poszczególnych grup przepisów. Dalsze zmiany i uzupełnienia w kodeksie cywilnym ${ }^{7}$, a także ujednolicenie i uporządkowanie terminologii pozwoliłyby, przy zachowaniu deklarowanej przez ten kodeks zasady jedności prawa cywilnego, wyodrębnić spójny zrąb przepisów będących podstawą prawnej regulacji działalności gospodarczej i zawodowej w nowych realiach gospodarczych RP.

32 Toward a European Civil Code, red. A.S. Hartkamp, Alphen aan den Rijn 1998. 


\section{Podsumowanie}

Przejście od dualizmu do jedności prawa cywilnego zostało wymuszone ustrojem gospodarczym PRL, który miał swoje podłoże totalitarne i autorytarne powodujące niemalże wyeliminowanie prywatnego obrotu gospodarczego i pozbawienie go większego znaczenia. Niemniej jednak wybór zasady jedności prawa cywilnego nie oznacza, że zasada ta ma swoje uzasadnienie tylko w tego typu ustrojach. Wręcz przeciwnie, można uznać ją za właściwą dla obowiązującej obecnie społecznej gospodarki rynkowej, a także innych kapitalistycznych ustrojów gospodarczych. Zmiany ustrojowe po 1989 roku w Polsce nie skłoniły więc ustawodawcy do powrotu do koncepcji dualistycznej regulacji stosunków majątkowych gospodarczych i cywilnych, ale zmierzają do poprawy jakości regulacji prawnych, czego przejawem jest obowiązujący obok kodeksu cywilnego kodeks spółek handlowych i jego liczne zmiany w kierunku zapewnienia bezpieczeństwa obrotu gospodarczego. Świadczy to też o tym, że zasada jedności prawa cywilnego mogła być nadużywana przez ustroje totalitarne, ale nie oznacza to przekreślenia jej wykorzystania $w$ innych ustrojach. Stąd zmiana z zasady dualizmu na zasadę jedności prawa cywilnego miała charakter wtórny w związku z potrzebami ustroju totalitarnego, ale odejście od autorytarnych rządów nie uzasadnia od razu powrotu do wcześniej obowiązujących reguł. Liczy się bowiem bardziej ewolucja przepisów w kierunku dostosowania ich do nowych warunków i ich interpretacja przez pryzmat obowiązującego ustroju, a więc wykorzystywanie potencjału tej zasady w praktyce obrotu gospodarczego. Zasada jedności prawa cywilnego nie tylko wykorzystywana jest w wielu krajach Europy o ustroju kapitalistycznym charakteryzujących się wolnością gospodarczą, ale też jest akceptowana w ramach Unii Europejskiej, gdzie obowiązująca swoboda przedsiębiorczości i wolność gospodarcza doskonale wykorzystują tą zasadę dla usprawnienia i zabezpieczenia bezpieczeństwa obrotu gospodarczego.

\section{Bibliografia}

Allerhand M., Komentarz do kodeksu handlowego, Lwów 1935.

Buczkowski S., Nowakowski Z.K., Prawo obrotu uspołecznionego, Warszawa 1974.

Całus A., Prawo cywilne i handlowe państw obcych, Warszawa 1979.

Całus A., Problematyka handlowa w reformie kodeksu cywilnego, „Przegląd Ustawodawstwa Gospodarczego" 1990, nr 8-10.

Czachórski W., Prace nad kodyfikacja prawa cywilnego, „Studia Prawnicze” 1970, nr 26-27. 
Frąckowiak J., Ustawodawstwo dotyczące przedsiębiorców pod rządami zasady jedności prawa cywilnego, „Przegląd Prawa Handlowego” 2000, nr 11.

Grzybowski S., System prawa cywilnego. Część ogólna, Wrocław 1985.

Iserzon E., Wokót koncepcji prawa gospodarczego, „Przegląd Ustawodawstwa Gospodarczego” 1956, $\mathrm{nr} 10$.

Janczewski S., Prawo handlowe. Wekslowe i czekowe, Warszawa 1946.

Konstytucja PRL z 22 lipca 1952 roku (Dz.U. z 1976 r. Nr 7, poz. 36).

Kruczalak K., Prawo obrotu gospodarczego, cz. 1. Zagadnienia ogólne, cz. 2. Prawo przedsiębiorstw, Gdańsk 1989.

Kruczalak K., Problem stosowania niektórych przepisów kodeksu handlowego, „Prawo i Państwo” $1987, \mathrm{nr} 6$.

Longchamps de Bérier R., Polskie prawo cywilne. Zobowiąania, Lwów 1939.

Makowska M., Makowski M., Zakaz propagowania komunizmu lub innego ustroju totalitarnego przez nazwy jednostek organizacyjnych, jednostek pomocniczych gminy, budowli, obiektów i urządzeń użyteczności publicznej oraz pomniki. Komentarz, Warszawa 2019.

Namitkiewicz J., Próba charakterystyki i określenia prawa handlowego, „Przegląd Prawa Handlowego" $1925, \mathrm{nr} 2$.

Prawo handlowe, red. J. Okolski, Warszawa 1999.

Rozporządzenie prezydenta RP z dnia 27 czerwca 1934 roku — Kodeks handlowy (Dz.U. z 1934 r. $\mathrm{Nr}$ 57, poz. 502 ze zm.).

Sołtysiński S., Szajkowski A., Szamański A., Szwaja J., Kodeks spółek handlowych. Komentarz do art. 1-150, t. 1, Warszawa 2012.

Stelmachowski A., Wstęp do teorii prawa cywilnego, Warszawa 1984.

Szczepaniak R., Węzłowe problemy stosowania prawa prywatnego w sektorze publicznym, „Ruch Prawniczy, Ekonomiczny i Socjologiczny” 78, 2016.

Toward a European Civil Code, red. A.S. Hartkamp, Alphen aan den Rijn 1998.

Wasilkowski J., Kodeks cywilny PRL a zagadnienie prawa gospodarczego. Tezy referatu przedstawionego na zebraniu Komitetu Nauk Prawnych PAN 12 II 1960 r., „Państwo i Prawo” 1960, nr 3.

Weiss I., Przeobrażenia prawa gospodarczego $w$ warunkach reformy gospodarczej, [w:] Problemy kodyfikacji prawa cywilnego. Księga pamiatkowa ku czci prof. Z. Radwańskiego, red. S. Sołtysiński, Poznań 1990.

Włodyka S., Polskie koncepcje prawa gospodarczego, „Przegląd Ustawodawstwa Gospodarczego” 1980, nr 4.

Włodyka S., Prawo gospodarcze. Zarys systemu. Część ogólna, t. 1, Warszawa 1981.

Włodyka S., Problem „prawa gospodarczego”, „Studia Cywilistyczne” 5, 1964.

Wolter A., Czy renesans koncepcji prawa gospodarczego?, „Przegląd Ustawodawstwa Gospodarczego" 1957, nr 3.

Wolter A., Ignatowicz J., Stefaniuk K., Prawo cywilne. Zarys części ogólnej, Warszawa 1999. 